Dossiê: Tradições Protestantes:

História de Mulheres e Relações de Gênero 



\title{
Katharina Schütz Zell, Idelette de Bure, and Reformed Women's Views and Experience of Marriage
}

\section{Katharina Schütz Zell, Idelette de Bure e as perspectivas e experiências de casamento de mulheres nos inícios da Reforma Protestante}

Elsie McKee ${ }^{1}$

\begin{abstract}
The Protestant movement had a significantly positive effect on early modern understandings of marriage, and women of the Reformed tradition participated actively in these changes. Protestants rejected celibacy as a good work to earn God's favor and elevated marriage as an ideal for Christians, including for clergy. One way that Reformed women expressed their faith was by marrying priests, thus acting on their conviction

1 Elsie McKee is Professor of Reformation Studies and the History of Worship at Princeton Theological Seminary. Her academic research has focused on the $16^{\text {th }} \mathrm{c}$. Reformation, particularly books on John Calvin and a woman reformer, Katharina Schütz Zell. She is probably best known for her trilogy on Calvin's doctrine of the ministries and worship of the church: John Calvin on the Diaconate and Liturgical Almsgiving (Droz, 1984), Elders and the Plural Ministry (Droz, 1988), and her newest book, The Pastoral Ministry and Worship in Calvin's Geneva (Droz, 2016). The two volume set Katharina Schütz Zell: The Life and Thought of a Sixteenth Century Reformer, and The Writings: A Critical Edition (both Brill, 1999), give attention to one of the most vivid and articulate women of the early Reformed tradition. She has published books of translations of both Calvin and Schütz Zell. McKee's teaching includes special interest in worship, Biblical exegesis and ethics, and gender and cross-cultural issues. McKee was born and reared in what is now the Democratic Republic of Congo, a heritage which formed her perspective on the world church, including the ways that the Reformed tradition has taken shape in at least one part of the Global South. Alongside teaching and research, McKee is involved in a number of non-profits which support education, medical work, and especially issues of gender and justice in Congo. She is the founder of Woman, Cradle of Abundance, Inc.
\end{abstract}


of Biblical authority (e.g., 1 Tim. 3) over canon law which prohibited clerical marriage. Former nuns, citizens of good reputation, married reformers as expressions of faith. A second way that Reformed women contributed to the new ideal of marriage was by the ways that they managed their households, making these models of hospitality and partnership in following Christ. A number of Reformed women chose exile for their faith and their Protestant husbands. A few, like Katharina Schütz Zell, were articulate in defending their decision to marry priests and their calling to serve as "church mothers." Some Reformed women, like Anne Askew, demonstrated their loyalty to their faith by rejecting marriage when it came to a choice between their faith and their marriages - or their lives.

\section{KEYWORDS}

Women; Katharina Schütz Zell; Idelette de Bure Calvin; clerical marriage; Biblical authority; partnership in ministry.

\section{RESUMO}

O movimento protestante teve um efeito significativamente positivo nos começos da compreensão moderna sobre o casamento, e as mulheres da tradição reformada participaram ativamente nestas mudanças. Os protestantes rejeitaram o celibato, considerado como boa obra para alcançar o favor de Deus, e consideraram o casamento como um ideal para os cristãos, inclusive para o clero. As mulheres da tradição reformada expressaram a sua fé foi casando-se com sacerdotes. Elas agiram desta forma a partir de suas convicções sobre autoridade bíblica (por exemplo, $1 \mathrm{Tm} 3$ ), em oposição à lei canônica que proibia o casamento clerical. Mulheres que deixaram de ser freiras, cidadãs de boa reputação, casaram-se com os reformadores como expressão de sua fé. Elas também contribuíram para o novo ideal de casamento na forma em que administravam as suas famílias, tornando-as modelos de hospitalidade e parceria no seguimento de Cristo. Algumas mulheres da tradição reformada escolheram o exílio por causa de sua fé e seus maridos protestantes. Outras, como Katharina Schütz Zell, defenderam a decisão de se casarem com os sacerdotes e do seu chamado para servir como "mães da igreja". Outras, como Anne Askew, demonstraram lealdade à sua fé ao rejeitar o casamento quando se tratava de uma escolha entre a fé e o casamento - ou suas vidas. 


\section{PALVRAS-CHAVE}

Mulheres; Katharina Schütz Zell; Idelette de Bure Calvin; casamento clerical; autoridade bíblica; parceria no ministério.

"God grant that our marriage may thus endure, as it is now, until the end. So I hope it will and may be pleasing to God and useful to both of our souls and advantageous in soul and body to many people. ... If we are driven out and must suffer death [for our faith], well, we still have the consolation that Christ says, 'You foolish and vexatious hearts, slow to believe all that the prophets have said: Must not the Christ suffer such things and thus come into His Kingdom?' ... Therefore we Christians should await the end in all patience; therefore have I placed myself and my husband in God's hands with a joyous heart; may His will be done in us! I know no greater honor we could experience than that we should die in disgrace with this world, and on the cross we would speak joyously to each other, he to me and I to him, to strengthen each other"2.

These are the words of Katharina Schütz Zell in 1524 when she and her new husband Matthew Zell were being slandered publicly for their marriage. Zell had been a Roman Catholic priest vowed to celibacy. When he became a "follower of the gospel," as Protestants called themselves, he had rejected what Protestants considered human traditions. Katharina Schütz had been a very devout young girl, who had privately pledged herself to virginity as the most holy Christian vocation. When she became convinced of the new understanding of the gospel which Martin Luther and Zell were preaching, she also renounced human traditions, including the idea that celibacy is a special and meritorious way to please God. So on Dec. 3, 1523, Katharina Schütz and Matthew Zell were married by Martin Bucer, a former monk who had already married a former nun ${ }^{3}$. What was going on here?

${ }^{2}$ SCHÜTZ ZELL, Katharina. Church Mother. The Writings of a Protestant Reformer in Sixteenth-Century Germany. Trans. ed. E. A. McKee. Chicago: University of Chicago Press, 2006, p. 79-80.

${ }^{3}$ MCKEE, Elsie Anne. Katharina Schütz Zell. The Life and Thought of a SixteenthCentury Reformer. Leiden: Brill, 1999. For Katharina Schütz's childhood, see chapter one; for the early reform, chapter two; for their marriage, p. 49. 
This presentation seeks to examine the thought and practice of marriage as it was explained and experienced by women of the early Reformed church. The first part explores something about the theology, particularly as that was expressed by Katharina Schütz Zell, one of the first women to marry a pastor. The second section discusses aspects of the actual marriages of leading Reformed women: Anna Reinhard Zwingli, Katharina Schütz Zell, Elisabeth Silbereisen Bucer, Margarete Drenss Hedio, Anna Adlischwyler Bullinger, Wibrandis Rosenblatt Keller Oecolampadius Capito Bucer, Marie Dentière, Idelette de Bure Calvin, as well as some rather different figures such as Anne Askew.

\section{I}

Although that fact is often forgotten, the question of marriage was a key aspect in Protestant theology and especially Reformed teaching. The issue has several dimensions. One was a changed view of holiness, of what it means to be set apart for God. In general, the medieval Roman Catholic perspective identified everything related to the church as holy: so priests, monks, and nuns who were separated from the world of married people were more holy than ordinary Christians. Churches and shrines and relics and altar cloths and statues of the Virgin Mary and the saints were more holy than ordinary people's houses or pots and pans or daily work. Saints' days were more holy than workdays. Note that all the people were Christian, all their world was shaped by the church's teaching. The point is that there were two ranks of Christians, two ranks of places and things and times. Some were closer to God and therefore able to be channels to help other people be saved, and some needed these special holy people and places and times and things to provide access to God.

Protestants challenged this division on the grounds of justification by faith alone, grace alone. If the means of salvation is purely God's gift, which is given without regard for human merit, then there are no people or places or times or things intrinsically closer to God than others. People are holy when they are forgiven and reconciled to God by trusting in Christ's grace, and this occurs only when the Holy Spirit moves them 
to trust. When this happens, everyone is on the same level in relationship to God. To put this in another way, every person who has this faith relationship with God can pray directly to God through Christ, the only Mediator. All people are priests, able to pray for themselves and for others. This new idea about who is holy and how one becomes set apart to God effectively made the Roman Catholic priests unnecessary.

A second dimension of the changes in the teaching on marriage was related to the other fundamental basis of Protestant theology: sola scriptura. Justification by faith and grace alone gave a new understanding of access to salvation, and sola scriptura gave a different perspective on what is the authoritative ground for theology. When Protestants said that the only doctrines which are binding must come from the Bible, they eliminated quite a lot of the church's ordinary teaching, or at least made it non-binding. This was very important for the teaching on marriage.

It is useful to summarize briefly the medieval views about women, sexuality, and marriage. These three are often closely connected for a number of reasons. In traditional societies, the main task of women is to be mothers, and this is also seen in much of the Bible, especially the Old Testament. In much of Christian history, sexuality has been associated with sinful desires; so in the medieval church married people were less holy than celibate people, and people who refused sexual life were regarded as especially spiritual. Marriage was not bad but it was considered a second-class kind of Christian lifestyle. It did serve two good purposes: procreation (to produce new Christians) and to be a remedy for immorality. Since being married and bearing children are often traditionally regarded as what defines a woman, women were essentially associated with sexual life. Because sexuality and women and marriage were associated, and sexuality was viewed in a negative way, women and marriage were also viewed in a negative way. On the other hand, denying sexuality was associated with being manly. For Roman Catholics, the way to be spiritual and holy was to vow celibacy (as Katharina Schütz did), and women who did this were praised for being "manly". In addition, vows of celibacy were seen as good works. When men or women took vows of celibacy, they were seen to be doing something extra, beyond what was necessary for salvation. They were doing good works to please God and earn God's favor. 
However, Protestants said that no one can do anything to earn God's favor; Christ has done it all. So there is no virtue in promising celibacy. In fact, God blessed marriage for Adam and Eve and made that the model way for believers to live. Sexuality is not evil but a part of God's good creation when it is used as God intended. The consequence of this theology was that Protestants made marriage the normal holy lifestyle ${ }^{4}$. Not everyone has to marry but marriage is both good in God's sight and the best way to serve God in the world. In fact, the Reformed tradition, led by Bucer and Calvin, actually revised the understanding of the purposes of marriage by focusing on its origin in Eden before the fall. According to this, the primary purpose of marriage is companionship in the faith, in serving God. The wife is the helpmate of the husband (Gen. 2:18); although she is still subordinate to her husband, without her he is incomplete, only half a person. With this change in doctrine, being a husband or a wife became a kind of partnership; though the man was dominant, both owed complete faithfulness to each other, each relied on the other as the one whom God had given in order to live a faithful life well. Being a mother or a father became a holy vocation, family life became the primary place where Christians lived out their callings to serve God. And this included ministers of the gospel.

So one of the ways that Protestant teaching on justification by faith alone grace alone and sola scriptura first became visible to many people was when their priests started to marry! As a new wife, Katharina Schütz knew that her marriage had caused a lot of scandalous talk. On the official level, the bishop of Strasbourg had disciplined her husband Matthew Zell and the other priests who had married and cast them out of their pulpits because they had broken canon law. On the popular level, some citizens praised Zell but others were attacking him; surely his theology was wrong or he would not have broken the church's laws of celibacy.

${ }^{4}$ For a good overview of Reformed thinking about marriage, the reformer Martin Bucer provides the most articulate - and for his day, radical - teaching. Calvin's teaching is also important though less radical. See SELDERHUIS, Herman. Marriage and Divorce in the Thought of Martin Bucer. Tran. J. Vriend \& L. D. Bierma. Kirksville, MO: Truman State Univ., 1999. For a summary of Calvin's teaching in the context of Genevan practice, see MCKEE, Elsie Anne. The Pastoral Ministry and Worship in Calvin's Geneva. Geneva: Droz, 2016, p. 357-75. 
There were also rumors of how he had mistreated his wife. First Katharina Schütz wrote to the bishop to defend the Biblical status of clerical marriage, but then she decided she needed to answer the slanders ${ }^{5}$. It was her Christian duty to defend the truth, which meant pointing out what was false and setting the record straight, in order not only to show that Zell was following the Bible but also to save the people who were turning away from the gospel because of the lies about the preacher. So in July 1524 Katharina Schütz published a pamphlet entitled Katharina Schütz's Apologia for Master Matthew Zell, her husband, who is a Pastor and Servant of the Word of God in Strasbourg ${ }^{6}$.

Katharina Schütz makes her argument about the marriage of clergy on several grounds. One is practical morality: many of the traditional priests did not keep their vows of celibacy and the bishops winked at this and even profited from it by taxing immoral priests for their concubines and children. Katharina Schütz describes in considerable detail the terrible effects of this immorality on the people, and the church itself because the system encouraged the bad behavior ${ }^{7}$. Naturally, the second ground for Katharina Schütz's defense of clerical marriage was the Bible. This is a case of sola scriptura, setting the teaching of the epistles to Timothy and Titus above the teaching of the church's tradition. By canon law, priests had to be celibate; according to the text of scripture, such as 1 Tim. 3, bishops and deacons were supposed to be married ${ }^{8}$. For this reason, the marriage of clergy became one of the very important markers of the early Reformation. It was a very clear way for Protestants to affirm that the Bible is the sole authority for salvation. In making this claim by marrying, Protestant ministers were also saying that they rejected the authority of Roman Catholic tradition and canon law.

For women like Katharina Schütz to marry priests could be a major statement of their faith. In some cases, the new pastors' wives were the priests' concubines. These women had for a long time been despised as immoral and had not had the right to participate fully in the rituals and

${ }^{5}$ SCHÜTZ ZELL, 2006, p. 71.

${ }^{6}$ SCHÜTZ ZELL, 2006, p. 62-82.

7 SCHÜTZ ZELL, 2006, p. 73-77.

${ }^{8}$ SCHÜTZ ZELL, 2006, p. 73-75. 
life of the church. Katharina Schütz knew at least a few who had managed to take care of themselves and she thought that they had the right to do so ${ }^{9}$. When priests married their concubines they were putting right the women's status and the status of their children, even though there was still a significant stigma attached to being the wife of a priest. What about the respectable women like Katharina Schütz who decided to marry priests? This was a step which demonstrated a very strong Protestant faith because they were risking their reputations - and possibly even the stability of their lives if the town where they lived did not become Protestant. Then they and their husbands might be exiled for breaking the church's law. In her pamphlet, Katharina Schütz included a defense of her decision to marry a priest. She begins by saying why she got involved, which was to address the problem of clerical immorality. "Do you mean that this is not my business? Then I say that I see how many souls already belong to the devil and continue so, which was also the reason that I have helped to raise up clerical marriage" ${ }^{10}$. She goes on to explain that "with God's help" she was the first respectable woman in Strasbourg to marry a priest, although she had not been intending to marry at all.

However, since I saw the great fear and furious opposition to clerical marriage, and also the great harlotry of the clergy, I myself married a priest with the intention of encouraging and making a way for all Christians - as I hope has also happened. Therefore I also made a little book, in which I showed the foundation of my faith and reason for my marriage ${ }^{11}$.

Although the idea of marrying in order to proclaim one's faith might seem strange to modern ears, this could be a very important sign for Protestant women to demonstrate their courage and commitment.

\footnotetext{
9 See PLUMMER, Marjorie E. From Priest's Whore to Pastor's Wife: Clerical Marriage and the Process of Reform in the Early German Reformation. Farnham, UK/ Burlington, NH: Ashgate, 2012. SCHÜTZ ZELL, 2006, p. 76.

${ }^{10}$ SCHÜTZ ZELL, 2006, p. 77.

${ }^{11}$ SCHÜTZ ZELL, 2006, p. 77.
} 
II

The lives of early Reformed women expressed clearly their convictions about marriage, even when often their words were not recorded. In this part of the presentation the first section tells briefly the stories of a number of outstanding Reformed women, especially wives of the Reformed leaders. The second section then summarizes the key aspects of their views on marriage as these can be discerned through their words or actions.

Many of the first generation Reformed pastors' wives give good glimpses into the experience of brave and faithful followers of the gospel. In 1522 Ulrich Zwingli secretly married a young widow named Anna Reinhart ${ }^{12}$. He had been preaching in the new Protestant way since he came to Zurich in Jan. 1519, but the city was still under the control of the bishop of Constance. Zwingli and his followers were acting on their Biblical convictions (such as eating meat in Lent) and one of his actions was to marry. But look at this from Anna's viewpoint: according to the laws of the church, she had become a priest's concubine! It was only in 1524 that the marriage was made public, after Zurich had voted to break with the Roman practice.

The story of Elisabeth Silbereisen Bucer is somewhat similar but in one sense even more shocking because both she and her husband broke their vows of celibacy ${ }^{13}$. Elisabeth had been a nun since she was a twelve, because when she was orphaned her relatives put her in a convent so they would not have to take care of her and could also have much of her inheritance. In the convent Elisabeth was often sick, and felt that being a nun kept her from living a truly Christian life. Thus, she decided to leave the convent because of her faith. In 1522 she married Martin Bucer, a priest and monk. He was accused of persuading her to abandon the life as a nun, but the two felt that God had called them to marriage and given them to each other. After some months when Bucer was serving as a pastor along with another married priest, the two clerical

12 BAINTON, Roland. Women of the Reformation in Germany and Italy. Boston: Beacon, 1971/1974, p. 161-162.

13 SELDERHUIS, 1999, p. 116-123. 
couples were driven out, so Bucer and Elisabeth came to his family's home city of Strasbourg. At this point Matthew Zell had not yet married, although his Protestant preaching was upsetting the bishop a great deal. Zell invited Bucer to preach from his pulpit - a scandalous thing to do! The small group of Protestants in Strasbourg welcomed the new pastoral couple, and Katharina Schütz and Elisabeth Silbereisen would become good friends. Elisabeth's life in supporting her husband's ministry was spent mostly caring for their home, bearing and rearing their many children (probably eleven, although only about five survived infancy), and welcoming guests, especially traveling Protestant ministers. She was an educated woman and sometimes corresponded with other Reformed women, but most of her time and energy went into the household. When she died of the plague in 1541, Bucer was heartbroken. Clearly, for some women the choice to marry a minister was an expression of faith in the face of much negative criticism.

Other important Reformed women in the German-speaking world add further details to the picture of how women understood their calling to marriage as ministry, and also highlights the cost when it led to conflict in their own families. Margarete Drenss was the daughter of a prominent Strasbourg family; she and her mother Agnes were among the early converts to Protestantism. When the reformer Caspar Hedio asked Margarete to marry him, she and her mother agreed. However, Margarete's brother Andreas objected vigorously: he was not a follower of the new teaching and he was determined that his sister was not going to become a priest's concubine and ruin the family's reputation. Then another leading Strasbourg citizen who was both a Protestant and a relative of the Drenss family stepped in to support the marriage (as if he were the women's male guardian) and Margarete married her preacher. Not long after this her brother also converted, so there was peace in the family again, but it must be remembered that a Protestant woman's choice to marry for her faith could demand great courage, including defying her family - and not everyone would have had a supportive relative to help her ${ }^{14}$.

Another similar case was that of Anna Adlischwyler, a young woman from an aristocratic background who became a nun in 1523 and was

\footnotetext{
${ }_{14}$ MCKEE, 1999, p. 54-55.
} 
living in the Oetenbach cloister in Zurich ${ }^{15}$. Several years later Anna met the new young reformer Heinrich Bullinger and he wanted to marry her. In fact, he wrote her a number of love letters over the course of their long courtship. The first was in 1527 and they became betrothed on Oct. 27, but Anna then tried to break off the relationship, probably because her widowed mother greatly objected. Bullinger continued to insist; a betrothal was legally binding, and he called on other ministers to help him convince Anna, but still she hesitated. It was not until Aug. 17, 1529, six weeks after her mother's death, that Anna and Bullinger were married. Then together they established a happy household which, like Bucer's, had many children who kept Anna busy. They also took in Zwingli's widow and children and other relatives and students. Anna's life was shaped by caring for her mother and then for everyone who came to her. When the plague came with great force in 1563 Anna nursed her husband through it but she and several of their children died.

Wibrandis Rosenblatt, the daughter of a citizen of Basel, had perhaps the most varied challenges in marriage and her life demonstrates the vital role of a reformer's wife - multiple times ${ }^{16}$. As a young woman she was married to a well-educated citizen of Basel named Keller; they had one daughter, but soon her husband died. Wibrandis and her family had become followers of the new gospel teaching. When Johannes Oecolampadius, the elderly priest reformer who led the movement in Basel, finally decided that he needed to marry in order to show his commitment to the Biblical faith, he asked this young widow to be his wife. There was a great difference in age between them, and Wibrandis would be taking on the disreputable role of a priest's concubine, but she agreed because she felt called to serve her faith in this way. Together they had several children. Since their father was a very learned scholar, he gave them names from history: a son Eusebius (an early church historian), and daughters Aletheia and Irene (Greek for truth and peace). But Oecolampadius died suddenly in 1531. So also did the wife of one of his friends, the Strasbourg reformer Wolfgang Capito, a colleague of Bucer and Zell and

${ }^{15}$ GISELBRECHT, Rebecca, "Myths and Reality about Heinrich Bullinger's Wife Anna". Zwingliana 38 (2011), p. 53-66.

${ }^{16}$ SELDERHUIS, 1999, p. 123-128. BAINTON, 1971/1974, p. 79-96. 
Hedio. Bucer thought that Capito needed a wife to take care of his children and Wibrandis needed a husband to support her family, so he suggested that they marry. They met and agreed to follow Bucer's advice.

To marry Capito Wibrandis had to move from Basel to Strasbourg; despite the strong ties between the two cities, this was a significant uprooting. She brought her children and her mother, and took over the care of Capito's household, and soon five more children arrived. However, life in the sixteenth century was very precarious, and another plague in 1541 was very severe; thousands of people died. Among them were a number of Wibrandis' children, Capito himself, and Bucer's wife Elisabeth Silbereisen and all but one of their surviving children. When Elisabeth was on her deathbed she heard that Capito had died. So she asked Katharina Schütz to go and bring the widowed Wibrandis to her home; there she made Bucer and Wibrandis promise to marry after her death. Very soon Elisabeth died and some months later Bucer and Wibrandis kept their word. Wibrandis brought her children from her previous marriages to Bucer's house and there established her new home, caring for his one surviving son and all the blended family. Several more children were born of this, Wibrandis' fourth marriage, though only one survived infancy. However, the plague was not the only major challenge Wibrandis faced with this husband; this time there was more political trouble which separated the family. When Roman Catholic forces defeated the Protestants, outspoken reformers like Bucer were exiled. He went to teach at Cambridge in England - a long and difficult journey away from Strasbourg. Wibrandis traveled there to care for him, although it was difficult juggling the children; she finally decided to leave one of the older daughters to care for Bucer while she returned to Germany to collect the rest of the family and come back to England. Not long after her arrival Bucer died, and Wibrandis moved once more, back to Strasbourg and then on to Basel with the children who were still at home. From Basel she continued to try to guide and care for all of the family. Her commitment to the gospel led Wibrandis to marry three priests, one after the other, enduring uprooting from her home, difficult travel, and constant childbearing as well as the many daily tasks of looking after leaders of the reform who were always busy with something else. 
All these women were from German-speaking lands where Protestantism began by the early 1520 s, but there were also important women's voices among the French and English-speaking Reformed. Marie Dentière is known as one of the first French women to talk about marriage as well as about her faith. ${ }^{17}$ She was an aristocratic nun, probably the prioress of her convent, when she was attracted to the new gospel teaching. France was strongly Roman Catholic so normally those who became Protestant had to go into exile. Dentière left her order and went to Strasbourg, which was the closest Protestant city, and there she married a former priest, Simon Robert. The couple joined William Farel in the work of spreading the gospel by preaching in the French-speaking area in the Rhone valley. After Robert's death, Marie was left with several small children. She married again, to another priest named Antoine Froment, with whom she came to Geneva to participate in the conversion of that city. Marie was involved in the first evangelical efforts - and she preached quite actively! - including especially to the cloistered Sisters of St. Clare, to whom she explained the goodness of marriage. (One of the nuns recorded how scandalized they were by this! $)^{18}$

Idelette de Bure, known as the wife of John Calvin, did not leave any written texts as Katharina Schütz and Marie Dentière did, but her life expressed poignantly her commitment to her faith and her marriage. Like Dentière, Idelette de Bure had to leave her home and go into exile because of her beliefs ${ }^{19}$.

${ }^{17}$ MCKINLEY, Mary B. "Introduction," Marie Dentière, Epistle to Marguerite de Navarre and Preface to a Sermon by John Calvin. Trans./ed. Mary B. McKinley. Chicago: University of Chicago Press, 2004.

18 JUSSIE, Jeanne de. The Short Chronicle. A Poor Clare's Account of the Reformation in Geneva. Trans./ed. Carrie F. Klaus (Chicago: University of Chicago Press, 2006, p. 151-152, quotes Dentière as saying "Oh, you poor creatures, if you knew what a good thing it is to be next to a handsome husband and how pleasing to God! Alas, I was for a long time in this darkness and hypocrisy where you are. But God alone showed me the delusions of my wretched life, and I saw the trust light of truth and realized I had been living in sorrow the whole time because in these convents there is nothing but hypocrisy, mental corruption, and idleness. And so, without hesitating I took five hundred ducats from the treasury and left that miserable life, and thanks to God alone I already have five fine children and I lead a good and healthy life." The nuns were "horrified" by these "false and deceitful words" p. 152.

${ }^{19}$ See DOUMERGUE, Emile. Jean Calvin. Les hommes et les choses de son temps. Tome second: Les premiers essais. Lausanne: Georges Bridel, 1902, p. 463, 466, 469. 
De Bure was a middle class woman like Katharina Schütz, but her home town did not convert to the new teaching of the gospel, so Idelette had to choose between her home and her faith. She was already married, with two small children, when she and her husband Jean Stordeur left Liège and moved to the Protestant city of Strasbourg. They were Anabaptists, reading the Bible literally and so rejecting infant baptism because it is not found in the New Testament. At this time Calvin was in Strasbourg because the Genevans had objected to his reforms and ordered him to leave. Since Strasbourg was German-speaking Bucer had called Calvin to be the pastor of the French-speaking religious refugees. In Strasbourg Idelette de Bure and Jean Stordeur encountered Calvin and came to accept his teaching and joined his congregation. After a time Stordeur died. Calvin had been looking for a wife but he had just about given up. The latest attempt had been by wealthy German-speaking Protestant friends who wanted him to marry one of the young women of their family. However, Calvin did not think that was a good match; his wife should be someone who shared his language and his social background as well as his faith ${ }^{20}$. Idelette de Bure was exactly right, and he asked the widow to marry him.

For Idelette, acccepting Calvin's proposal meant complicating her life further. She was already in exile, and now she was adding the disadvantages of marriage to a minister; and to make it worse, Calvin was very poor. But she believed this was her call. She had chosen exile for herself and her children, in order to be able to live out her faith, and now she was willing to accept more challenges like those of other women who married these new Protestant pastors. When they moved to Geneva in 1541, Idelette and Calvin no longer had financial problems but they had a very difficult church situation. Calvin and his ideas about reforming the life of the church were no more popular than they had been when Geneva first exiled him, so Idelette lived in the context of many church arguments, even as she visited the sick and welcomed all the travelers who visited Calvin. Neither Idelette nor Calvin was in good health; their only known child died as an infant and she was never really well again. It is possible to get a glimpse of Idelette's faith through the letters Calvin

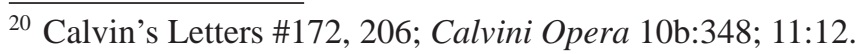


wrote to his two closest reformer friends, Farel and Viret, when he described her death and their life together.

Intelligence of my wife's death has perhaps reached you before now. I do what I can to keep myself from being overwhelmed with grief. ... And truly mine is no common source of grief. I have been bereaved of the best companion of my life, of one who, if anything more difficult had befallen me, would not only have been the willing sharer of my exile and indigence, but even of my death. During her life she was the faithful helper of my ministry ${ }^{21}$.

Calvin names exile, poverty, and death; Idelette had shared both exile and poverty, and he is sure that if necessary she would have shared death with him, as companions in their service to God. For the full impact of these words, it is important to remember that Calvin was writing to the two men to whom he was closest, who had been his fellow reformers from the beginning; it is the highest praise he could give. And this tells us something about the way that Idelette de Bure lived her faith through her marriage, embodying the Reformed ideal of partnership in the faith, wherever that might lead them. Her final words on her deathbed were recorded by Calvin as a testimony to her faith. "O glorious resurrection! O God of Abraham and of all our fathers, in You have the faithful trusted during so many past ages, and none of them have trusted in vain. I also will hope" 22 .

There is another aspect of Reformed women and marriage, one could say it is the other face of the ministries. These were women whose husbands did not share their faith; they had to choose between their convictions and their marriages. One of these was the English martyr Anne Askew who was burned at the stake under Henry VIII in July $1546^{23}$. Anne came from a good family which already had some interest in the

${ }^{21}$ Writings on Pastoral Piety, pp. 52, 53-54. First sentence from April 2, 1549, to Farel; remainder from April 7, 1549, to Viret. Letters \#1171 and \#1173, Calvini Opera $13: 229,230$.

22 April 2, 1549. Writings on Pastoral Piety, pp. 52-53. Letter \#1171, Calvini Opera 13:229.

${ }^{23}$ BEILIN, Elaine V. "Introduction," The Examinations of Anne Askew. Ed. E. V. Beilin. New York/Oxford: Oxford University Press, 1996), p. xv-xxiv. 
new Protestant teaching, although England at the time was still essentially catholic. Henry had broken with the pope and made himself head of the church but his theological orientation remained conservative. Anne was arrested in 1545 because she insisted on scripture alone, rejected transubstantiation, and broke Henry's law by going into the church and reading the Bible aloud. (Only priests were permitted to do that.) Some of Anne's relatives arranged to get her released but she did not change her theology, and the next year she was arrested again and tried a second time, and this time she was sentenced to death. Both of her examinations show how articulate and well-informed Anne was in her faith. One of the questions she was asked concerned her name. Some people called her Anne Kyme, because she was married to a man named Kyme, but he had rejected her as a heretic, so she used her maiden name Askew ${ }^{24}$. Clearly, for Anne, her faith in the gospel and her determination to keep to the teaching of the Bible against everything that the Roman Catholic clergy said, decided her attitude toward marriage. She did not reject her husband but she would not give up her faith in order to save her marriage - or her life.

\section{III}

As can be seen, many Reformed women made choices about marriage because of the choices they had already made about their faith. Most of these strong and devout women did not write about their convictions, so in order to understand their beliefs one must extrapolate from what they did. Katharina Schütz, however, is the exception, and she provides a vivid picture of the partnership of her marriage with Matthew Zell.

The Zells were a rather unusual couple, even by the standards of the new vocation of pastor's wife. In the first section of this paper we saw how and why Katharina came to marry Matthew and how she defended clerical marriage. In this section the purpose is to discuss briefly how she described her married life when she was an elderly widow looking back. ${ }^{24}$ The Examinations of Anne Askew. Ed. E. V. Beilin. New Yorl/Oxford: Oxford Uni-
versity Press, 1996), p. 175, 180. 
It is important to note that the main reason she wrote about her marriage was because she was being attacked by a young man who had been like a foster son. He accused her of heresy and disturbing the church and causing trouble for her husband... and Katharina would not tolerate that slander. So she set out to explain exactly how Matthew and Bucer and the rest of the first generation had risked their lives for their faith, and what that teaching was. And she emphasized that she had shared it! In addition, Katharina described how much Matthew had approved and supported her as his partner.

The Zells' marriage was both similar to that of the other reformers and different ${ }^{25}$. Like all the pastors' wives, Katharina cared for a busy household which was expected to function as a guesthouse for visiting reformers and a refuge for people in need. This was a role which both Zells took very seriously, and Katharina actively invited into their home anyone who was in need. To their great sorrow, the Zells' own two babies died in infancy, but they cared for relatives and orphans and more. One time Katharina suddenly was called upon to provide housing for eighty men who were forced to leave their homes for their faith and to feed twice that many; another time she gave a home to an exiled minister and his family for the entire winter; another time she arranged a dinner for a big Protestant conference but spent the time nursing a sick member of it. And the story goes on. At other times, Katharina defended people whom some Protestants considered unorthodox, and she never failed to help anyone in need - though she would also probably preach to them as well as feed them! According to Katharina, Matthew was more than willing to give her time and service to the parish and church community.

So, constantly, joyously, and strongly, with all good will have I given my body, strength, honor, and goods for you, dear Strasbourg, I have made them a footstool for you. My devout husband too was very heartily glad to allow this, and he also loved me very much for it; he often allowed there to be something lacking in his own physical and

\footnotetext{
${ }^{25}$ For a full picture of Katharina Schütz's life, see MCKEE, Elsie Anne. Katharina Schütz Zell. The Life and Thought of a Sixteenth-Century Reformer. For a shorter summary, see MCKEE, Elsie Anne. "Introduction" to Katharina Schütz Zell, Church Mother, p. 14-24.
} 
household needs because of my absence and gladly sent me as a gift to the community; also, at his death he commended me to continue such activity - not with a command, but with a friendly request ${ }^{26}$.

However, busy as she was with the care of her husband's parish, Katharina was also determined not to miss continuing to learn, and she loved to read: the Bible, the writings of Luther and other reformers, religious texts. She said that Matthew encouraged her to study and weigh everything by scripture. "[W]hen [Zell] was alive he never hindered or forbade [my reading or studying] but always told me (as he himself also did) to read and listen, and so, after testing (as they do with the stone that is used to try gold), to hold to the good"27. Katharina was also included in conversation at the dinner table, where she discussed theology with the guests, arguing and explaining her views politely but firmly. Marriage meant a lifelong growing in faith and serving the church alongside Matthew and then continuing their shared work after his death.

The most notable or controversial aspects of Katharina's view of marriage came from her conviction that she was Matthew's partner in teaching and sharing the gospel. She would welcome people but she was also compelled to preach (informally) and educate and correct them, as well as carry on pastoral visitation. Katharina said that Matthew called her his assistant minister.

I have also - God be praised! - taught much in those place [homes, prisons, etc.], and affirm before God that I have done more work, of body and tongue, than any assistant (helffer) or chaplain of the church; I have watched and run, night and day, and many times I have neither eaten nor slept for two or three days. Therefore also my devout husband (whom this so well pleased) only called me his assistant minister (helffer), even though I also never stood in the pulpit, nor did I need to do so for my work ${ }^{28}$.

${ }^{26}$ SCHÜTZ ZELL, 2006, p. 224-225.

${ }^{27}$ SCHÜTZ ZELL, 2006, p. 194.

${ }^{28}$ MCKEE, 1999, p. 449. See p. 441-49 for Katharina Schütz's description of their married partnership. 
(This clear statement of her own pastoral work was addressed the educated and arrogant young man who was Zell's official assistant - and he was furious!) For Kathrina Schütz, teaching the gospel, "fishing for people," was not just for men; it was for everyone, and she was determined to do her part ${ }^{29}$. Some people she could reach in person but others were too numerous or too far away so Katharina decided to print some of her teaching. During Matthew's lifetime she published various devotional texts especially for women and children. But after he died she seemed to believe she was called to continue his pastoral work; she preached to his congregation at his burial, and she carried on visiting the sick and poor. Glimpses of her ministry are visible in her later publications, as she spoke and wrote to comfort and strengthen "her" parishioners and to defend the teaching of the first generation Strasbourg reformers. Marriage for Katharina began as an affirmation of her faith and it was lived as an affirmation of the importance of a partnership with her husband in service to God. The people of Strasbourg seem to have accepted this as a fact, and regarded her as an extension of Matthew; the two were God's servants in ministry, two bodies but one calling.

\section{IV}

Katharina Schütz Zell, Idelette de Bure Calvin, and many other women lived out the new Reformed perspective on the purpose of marriage. One important concern was to address immorality: people were lax because their religious guides were lax, so a new standard of behavior had to begin with a right lifestyle for ministers of the church. Many women of the first generation explicitly understood it to be their calling to create a new image of what a pastor's household should be. They wanted to correct the traditional view of clergy as those who vowed an impossible celibacy and then did not live up to it, and they were willing to risk their own reputations to serve the church in this way. They also shared the Protestant teaching which redefined the means of salvation as justification by faith alone grace alone, on the basis of the Bible as the

${ }^{29}$ MCKEE, 1999, p. 440. 
sole authority for knowing God's will. For this reason they welcomed the calling of motherhood, not as a second-class rank but as part of the true religious vocation of God's daughters. This maternal role extended far past their own families, and meant that they regularly offered hospitality to a great many people for both short term and long term stays in their homes, becoming mothers to the church. Because they also shared the Protestant view that sexuality in marriage is good, these women claimed their role as wives with pride as a way to fulfill God's will.

It was a particularly Reformed addition to teach that the original and primary purpose of marriage is companionship in the faith, and these women very clearly believed and lived that out. Few were as outspoken as Katharina Schütz in affirming publicly that she was Matthew's partner, but she voiced what these Reformed women expressed in their lives. They did not claim equality. However, they actively embraced their belief that the Christian church and society should be built on the partnership of husbands and wives in service to God and neighbors, and they acted on their conviction that marriage and motherhood are holy callings for women just as marriage and fatherhood are holy callings for men.

\section{Bibliography}

BAINTON, Roland. Women of the Reformation in Germany and Italy. Boston: Beacon, 1971/1974.

BEILIN, Elaine V. "Introduction," The Examinations of Anne Askew. Ed. E. V. Beilin (New York/Oxford: Oxford University Press, 1996, p. XV-Xxiv.

DOUMERGUE, Emile. Jean Calvin. Les hommes et les choses de son temps. Tome second: Les premiers essais. Lausanne: Georges Bridel, 1902.

GISELBRECHT, Rebecca, "Myths and Reality about Heinrich Bullinger's Wife Anna". Zwingliana 38 (2011), p. 53-66.

Joannis Calvini opera quae supersunt omnia. Disponível em: https:// archive-ouverte.unige.ch/unige:650.

JUSSIE, Jeanne de. The Short Chronicle. A Poor Clare's Account of the Reformation in Geneva. Trans./ed. Carrie F. Klaus. Chicago: University of Chicago, 2006. 
McKEE, Elsie Anne. "Introduction" to Katharina Schütz Zell. In: Church Mother. The Writings of a Protestant Reformer in Sixteenth-Century Germany. Trans. ed. E. A. McKee. Chicago: University of Chicago Press, 2006, p. 14-24.

MCKEE, Elsie Anne. Katharina Schütz Zell. The Life and Thought of a Sixteenth-Century Reformer. Leiden: Brill, 1999.

MCKEE, Elsie Anne. The Pastoral Ministry and Worship in Calvin's Geneva. Geneva: Droz, 2016.

MCLINKEY, Mary B. "Introduction," Marie Dentière, Epistle to Marguerite de Navarre and Preface to a Sermon by John Calvin. Trans./ ed. Mary B. McKinley. Chicago: University of Chicago, 2004.

PLUMMER, Marjorie E. From Priest's Whore to Pastor's Wife: Clerical Marriage and the Process of Reform in the Early German Reformation. Farnham, UK/ Burlington, NH: Ashgate, 2012.

SCHÜTZ ZELL, Katharina. Church Mother. The Writings of a Protestant Reformer in Sixteenth-Century Germany. Trans. ed. E. A. McKee. Chicago: University of Chicago Press, 2006.

SELDERHUIS, Herman. Marriage and Divorce in the Thought of Martin Bucer. Tran. J. Vriend \& L. D. Bierma. Kirksville, MO: Truman State Univ., 1999.

Submetido em: 25/05/2017 Aceito em: 26/06/2017 